Косінова Олена Миколаївна, кандидат педагогічних наук, доцент, Заслужена артистка України. kosinova@meta.ua

\title{
КОРПОРАТИВНА КУЛЬТУРА ЯК ВАГОМИЙ ЧИННИК ПРОФЕСІЙНОЇ ПІДГОТОВКИ ТЕЛЕВЕДУЧИХ
}

\begin{abstract}
Мета роботи - розкрити сутність процесу упровадження корпоративної культури в системі естетичної спрямованості професійної підготовки телеведучих. Методологія дослідження передбачає комплексний підхід із застосуванням аналітичного, системного методів, компаративного, що дозволяе зрозуміти, що ідеал мистецької освіти потребує змістовного наповнення, створення оптимальних умов для корпоративної культури в системі естетичного життя студентів вишу культури і мистецтв. Наукова новизна роботи полягає в актуалізації концепту корпоративної культури у контексті та зв'язку з формуванням професійної підготовки телеведучих. Висновки. В результаті проведеного дослідження встановлено, що в умовах творчого вишу впровадження естетичної спрямованості професійної підготовки студентів здійснюється шляхом формування особистості митця з гармонійно поєднаними професійними, морально-естетичними, психологічними якостями і забезпечується цілеспрямованою навчально-виховною діяльністю. Найважливішими естетичними якостями в процесі формування корпоративної складової естетичної підготовки майбутніх телеведучих $є$ такі: повага до історії, культури, гідності, етичних ідеалів кожного народу; інтерес до національної мови, звичаїв, традицій, а також наявність почуттів взаємної толерантності та делікатності як стосовно національно «іншого» менталітету, духовних цінностей, так і носіїв іншої культури та думок , що не співпадають 3 власними.
\end{abstract}

Ключові слова: корпоративна культура, естетична спрямованість, інформаційне суспільство, творча діяльність, культурна спадщина, естетичний смак, естетичне життя.

Косинова Елена Николаевна кандидат педагогических наук, дочент, заслуженная артистка Украины Корпоративная культура как важный источник професиональной подготовки телеведущих

Цель работы - раскрыть сущность процесса внедрения корпоративной культуры в системе эстетической направленности профессиональной подготовки телеведущих. Методология исследования предполагает комплексный подход с применением аналитического, системного методов, компаративного, что позволяет понять, что идеал художественного образования требует содержательного наполнения, создания оптимальных условий для корпоративной культуры в системе эстетической жизни студентов вуза культуры и искусств. Научная новизна работы заключается в актуализации концепта корпоративной культуры в контексте и связи с формированием профессиональной подготовки телеведущих. Выводы. В результате проведенного исследования установлено, что в условиях творческого вуза внедрение эстетической направленности профессиональной подготовки студентов осуществляется путем формирования личности художника с гармонично соединенными профессиональными, морально-эстетическими, психологическими качествами и обеспечивается целенаправленной учебновоспитательной деятельностью. Важнейшими эстетическими качествами в процессе формирования корпоративной составляющей эстетической подготовки будущих телеведущих являются: уважение к истории, культуре, достоинства, этических идеалов каждого народа, интерес к национальному языку, обычаям, традициям, а также наличие чувств взаимной толерантности и деликатности как относительно национально «другого» менталитета, духовных ценностей, так и носителей другой культуры и мыслей, которые не совпадают с собственными.

Ключевые слова: корпоративная культура, эстетическая направленность, информационное общество, творческая деятельность, культурное наследие, эстетический вкус, эстетическое жизни.

\section{Kosinova Olena, Candidate of Pedagogical Sciences, Honored Artist of Ukraine, assistant professor}

Aesthetic Education as Actual Training Direction of Arts High School Students

The purpose of the work is to reveal the essence of the process of introduction of corporate culture in the system of aesthetic orientation of professional training of TV presenters. The research methodology involves a comprehensive approach with the use of analytical, systematic, and comparative methods, which makes it clear that the ideal of art education needs a meaningful content, creating optimal conditions for corporate culture in the system of aesthetic life of students of higher education and arts. The scientific novelty of the work lies in updating the concept of corporate culture in the context and in connection with the formation of professional training of broadcasters. Conclusions. As a result of the conducted research it is established that in the conditions of creative higher education the implementation of the aesthetic orientation of students' professional training is carried out by forming the personality of the artist with harmoniously combined professional, moral and aesthetic, psychological qualities and is provided with purposeful educational activities. The most important aesthetic qualities in the process of forming the corporate component of aesthetic training of future TV presenters are the following: respect for the history, culture, dignity, ethical ideals of each people; interest in the national language, customs,

СКосінова О. М., 2019 
traditions, as well as feelings of mutual tolerance and delicacy as to the national "other" mentality, spiritual values, and carriers of another culture and opinions that do not coincide with one's own.

Keywords: corporate culture, aesthetic orientation, information society, creative activity, cultural heritage, aesthetic taste, aesthetic life.

Актуальність теми дослідження. Здійснюючи впровадження оволодіння корпоративною культурою в системі естетичної спрямованості професійної підготовки студентів, слід звертати увагу на те, що зазначений процес проводиться 3 майбутніми фахівцями системи телеіндустрії. Цей образ належить до ідеального, а ідеал освіти потребує змістовного наповнення. Ідеал сучасного телеведучого має бути зрозумілим студентам та вишу, який здійснює навчально-виховний процес. При цьому вкрай небажаним $є$ абстрактний образ майбутнього митця. Він повинен вбирати в себе якості, властиві всім творчим особистостям мистецьких спільнот України, незалежно від виду професійної діяльності, і вже потім доповнюватися професійними знаннями, уміннями та мотивами діяльності. Такий підхід надає можливість припустити, що особистість митця визначається громадською свідомістю як індивідуальна цілісність, яка містить інтелектуальну, моральноестетичну, емоційну, вольову розвиненість.

Аналіз досліджень і публікацій. Питанням вивчення корпоративної культури присвячені праці Н.Абашкіної, С.Василенко, О.Козирєвої, О.Медведєвої, Н.Могутнової Т.Персикової, П.Смоленюк, О.Тарасової та ін. Різні аспекти підготовки телеведучих вивчали у роботах О.Гончарова, Т.Захарас, Т.каратай, В.Костюк, О.Клімашевська, І.Крупський, Т.Лункіна, Ю.Снурнікова, В.Чекалюк та ін. Водночас питання корпоративної культури як чинника професійної підготовки означеного напряму фахівців $є$ малодослідженими, що складає актуальність пропонованої статті.

Мета роботи - розкрити сутність процесу упровадження корпоративної культури в системі естетичної спрямованості професійної підготовки телеведучих.

Виклад основного матеріалу. Майбутній митець опановує професію на основі науковотехнічного знання, удосконалює в собі правові, економічні, художньо-естетичні якості з метою формування свого внутрішнього світу, створення самого себе як духовно розвинутої особистості. Студент характеризується широким кругозором, високим професіоналізмом, глибокою духовністю і непохитною вільною моральною волею, естетичним ставленням до дійсності й особливістю мислення як інструменту досягнення та освоєння цього складного світу.

Можливості навчального-виховного процесу під час формування у студентів естетичної складової професійної підготовки необхідно розглядати з двох основних позицій:

естетичних можливостей організації навчально-виховного процесу НПС ВУЗу;

участі студентів у практичній діяльності з естетизації навчального середовища в процесі навчальної діяльності;

Естетичний вплив науково-педагогічного складу $\epsilon$ необхідною умовою формування у майбутніх митців відчуття прекрасного, радості пізнання суспільних явищ. Науково-педагогічний склад прагне з перших же занять використовувати всі можливості своїх дисциплін для розвитку у студентів естетичних поглядів і смаку, розкриває перед ними естетичні особливості навчальних дисциплін.

Структура навчально-виховного процесу передбачає наявність чітко визначених виховних цілей. В умовах мистецького ВУЗу виховний процес спрямовано на:

- формування цілісної особистості студента - спеціаліста визначеного профілю;

- $\quad$ патріотичне та правове виховання студента - справжнього громадянина Батьківщини;

- формування високих моральних якостей;

- гармонійність розвитку інтелектуальної, почуттєвої, вольової та фізичної сфер особистості;

- естетичне виховання та розвиток здібностей щодо естетично-художньої творчості;

мотивацію самовиховання і формування готовності виховувати підлеглих тощо.

Педагогічна діяльність з упровадження естетичної спрямованості професійної підготовки студентів містить:

- навчально-виховний процес та організацію навчання;

- позанавчальну діяльність і організацію дозвілля;

- самостійну естетико-художню творчість.

Кожен з означених елементів педагогічної діяльності передбачає використання відповідних методів, прийомів та форм роботи.

Особливість упровадження естетичної спрямованості професійної підготовки визначається 3 тієї точки зору, що на кожному курсі навчання у структурі пізнання і поведінки діють свої естетичні 
вимоги корпоративної культури. Вони створюються у процесі практичного засвоєння світу й $\epsilon$ взаємопов'язанними 3 усіма компонентами формування корпоративної складової естетичної підготовки студентів.

Важлива особливість упровадження естетичної спрямованості професійної підготовки студентів полягає в тому, що зазначений процес може здійснюватись як через вплив на особистість естетичних властивостей предметів та явищ навколишнього середовища, так і за допомогою літератури та мистецтва. Основними засобами впровадження корпоративної складової естетичної спрямованості професійної підготовки студентів $\epsilon$ : навчання, процес пізнання, праця, побут, спілкування, творчість, література і мистецтво.

Естетичні почуття студентів викликають такі елементи учбової діяльності, як гармонія, симетрія, пропорція, ритм, темп. Учбова діяльність та навчання активно впливають на корпоративну культуру студентів такими складовими: власне процесом діяльності; змістом навчання; стосунками під час учбової діяльності; результатами навчально-виховного процесу.

Навчально-пізнавальний процес має суттєві можливості для впровадження корпоративної спрямованості в системі естетичної професійної підготовки студентів. Проникаючи думкою у сутність предметів, процесів та явищ, які пізнаються, майбутній спеціаліст одночасно сприймає властиві їм естетичні якості. На заняттях НПС, використовуючи художні засоби, яскраво, образно і дохідливо розкриває красу творчості під час виконання учбових завдань.

Прекрасне у житті та навчанні $\epsilon$ i засобом, і результатом упровадження корпоративної складової естетичної спрямованості підготовки майбутніх тележурналістів.

При проведенні позанавчальної роботи з студентами проводяться лекторії з видів та жанрів мистецтва, літературні вечори і бесіди, зустрічі з видатними артистами, художниками, діячами літератури та кіномистецтва, відвідування художніх виставок, музеїв, театральних вистав, кінотеатрів, телестудій тощо. Означена робота сприяє опануванню кожним студентом навичок і вмінь творити прекрасне у житті та мистецтві. Логіка впровадження естетичної спрямованості професійної підготовки студентів потребує його повної доцільності і запобігання будь-яких шаблонів.

Практично естетичний елемент корпоративного спілкування $\epsilon$ в кожному навчальному предметі. Такі естетичні категорії, як симетрія, пропорційність, колір, міра, звук, гармонія, стосуються не лише до живопису, поезії, музики. Ними оперують навчальні дисципліни, що вивчаються, а саме: «Сценічний рух», «Основи сценарної майстерності», «Акторська майстерність», «Теорія драми», «Операторська діяльність» та ін.

На заняттях 3 «Сценічного руху» та «Акторської майстерності» поняття гармонії, симетрії, пропорційності, ритму набувають естетичного звучання, коли вони сприймаються студентами як конкретний вираз засвоєння на практиці певної закономірності корпоративного спілкування, закономірності корпоративної культури. Інтерес студентів до навчання посилюється, коли НПС не тільки показує їм в процесі викладу навчального матеріалу репродукції, художні фотознімки, сучасні кіноматеріали, конструкції костюмів, елементи акторської техніки, сценарні плани, та сценарії різних телепрограм, але й пропонує самостійно знайти деталі,елементи в своїх творчих роботах що містять елементи гармонії, естетики, елементи корпоративної культури тощо.

Викликає відчуття захоплення гармонія природи, іï барвистість, різноманітний рослинний i тваринний світ, які розкриваються перед студентами в процесі зйомок екологічних тем, проблем екології, що оточує нас. Адже, сама природа є багатим джерелом естетичних переживань. У кожний момент навколишня природа вносить щось прекрасне, що облагороджує почуття, впливає на весь духовний стан особистості. Гармонійною є не лише окрема рослина, тварина. Гармонія - в єдності їх розвитку з умовами життя, із зовнішнім середовищем. Усестороннє вивчення рослин, тваринного світу надає можливість управляти їх красою, служити людині. До такого висновку приходять студенти, що акцентують тематику своїх робіт саме на екологічних проблемах.

У процесі вивчення дисциплін загальноосвітнього, загальноестетичного та спеціального циклів студенти переконуються в тому, що краса і доцільність $є$ взаємозв'язаними, що поглиблене вивчення наук надає змогу виявляти та збільшувати красиве в процесі практичної діяльності людини.

Уважне використання НПС наукових знань про природу, творчих біографій учених, митців, артистів, досвіду практичної діяльності викладачів відкривають широкий простір для виховання у студентів глибоких патріотичних почуттів естетичного сприйняття дійсності, відчуття краси пізнання світу.

Найважливішою передумовою розвитку естетичних почуттів, поглядів і смаків студентів у процесі навчання $є$ використання художніх образів. Органічним елементом кіномистецтво входить не лише у викладання «Історія кіно та телебачення». Багато осіб НПС прийшли до висновку, що 
використання творів кіномистецтва на заняттях усіх дисциплін, які вивчаються, значно підвищує зацікавленість курсантів змістом навчального матеріалу, стимулює активність, підвищує якість знань.

Велику роль в корпоративній культурі в системі естетичного виховання відіграє вивчення курсу «Філософія». У цьому курсі практично немає такої теми, де б не надавалась можливість використовувати твори кіномистецтва, художньої літератури, живопису, музики, театру.

Можна використовувати на заняттях матеріали періодичного друку. Вирізки з газет, журналів підбираються відповідно до розділів програми, потім демонструються на заняттях у процесі викладу матеріалу. Вони використовуються як наглядний засіб для ввідної бесіди до нової теми, при підготовці студентів до сприйняття нового матеріалу, на семінарських заняттях.

Різноманітна гамма почуттів, у тому числі й естетичних, пов'язана з використанням у процесі навчання образу мистецтва, кіно і телебачення, 3 розповідями про творчу діяльність митців, 3 умінням НПС показати взаємозв'язок ззовні ніби розрізнених явищ, з постійним виникненням відчуття здивування студентів від нових фактів тощо. Розширення емоційної сфери сприяє розвитку творчих здібностей майбутніх митців, формуванню у студентів прагнення самостійно мислити, міркувати, вирішувати навчальні завдання. Відомо, що людина найбільшу насолоду отримує від того, що сама зробила, куди вклала власну працю, душу. Тому в формуванні естетичної складової професійної підготовки студентів враховується такий важливий аспект як потенційні можливості самих студентів, створення належних умов для їх естетичного самовираження, вияву їх естетичного досвіду.

Стосовно структури впровадження корполративної спрямованості професійної підготовки студентів під час дослідження виокремлено етапи зазначеного процесу, а саме: діагностичний, проектуально-цільовий, організаційний, стимулюючо-спонукальний, контрольно-оціночний. Виокремлені етапи впровадження корпоративної спрямованості професійної підготовки студентів надають можливість стимулювати студентів до досягнення вершин як в особистому, так i професійному плані.

Спонукальними чинниками в упровадження корпоративної спрямованості професійної підготовки студентів можуть бути й образ продуктивної творчої діяльності самого педагога, який засобами своєї професії прагне прищепити своїм вихованцям кращі людські риси. Основним елементом ефективності впровадження корпоративної спрямованості професійної підготовки студентів $є$ сформованість у студентів потреби і вмінь у сфері самовиховання, самоосвіти, самоорганізації, самоконтролю. У межах кожного елементу педагогічної діяльності з впровадження корпоративної спрямованості естетичної підготовки студентів використовуються специфічні форми роботи.

Сучасна педагогіка визначає такі види виховання: патріотичне, правове, моральне, професійне, естетичне, фізичне тощо. Водночас види виховання перебувають у постійній та тісній єдності, кожен 3 них має естетичний аспект.

Важливе значення в упровадженні корпоративної спрямованості естетичної підготовки студентів в умовах гуманізації і гуманітаризації вищої школи України має естетичне виховання. Відомо, що люди в житті дуже велике значення надають прекрасному. Людина сама хоче бути красивою та прагне зробити красивою одяг, житло, предмети побуту, знаряддя праці, архітектуру будівель, усе ії навколишнє оточення. Вона вносить красу і в працю і у відпочинок.

Навчально-виховний процес ВНЗ активно стимулює естетичний розвиток особистості. Кожний навчальний предмет має значні можливості для впровадження естетичної спрямованості професійної підготовки студентів. Усі форми навчальної діяльності: лекції, семінари, практичні заняття, тренування, репетиції - характеризуються певним рівнем естетичного навантаження. Зокрема, практичні заняття, зокрема прогоні, репетиції не лише дають знання, формують творче мислення та розвивають навички управління творчим колективом, привчають бачити красу узгоджених і рішучих дій, розуміти естетичні основи у доцільній колективній діяльності. Індивідуальні заняття, наприклад, із акторської майстерності, сценічної мови виховують у студентів акуратність та зібраність, привчають їх до чітких, узгоджених і красивих дій. На заняттях із суспільних наук НПС має можливість показати красу піднесеного та героїчного і довести нікчемність непристойного, потворного. Важливу роль у впровадженні естетичної спрямованості професійної підготовки майбутніх митців відіграє вивчення дисциплін: етики й естетики, культурології, рідної та іноземної мов, а також педагогіки та психології.

Наукова новизна роботи полягає в актуалізації концепту корпоративної культури у контексті та зв'язку з формуванням професійної підготовки телеведучих. 
Висновки. Отже, в умовах творчого вишу впровадження естетичної спрямованості професійної підготовки студентів здійснюється шляхом формування особистості митця з гармонійно поєднаними професійними, морально-естетичними, психологічними якостями і забезпечується цілеспрямованою навчально-виховною діяльністю. Найважливішими естетичними якостями в процесі формування корпоративної складової естетичної підготовки майбутніх телеведучих є такі: повага до історії, культури, гідності, етичних ідеалів кожного народу; інтерес до національної мови, звичаїв, традицій, а також наявність почуттів взаємної толерантності та делікатності як стосовно національно «іншого» менталітету, духовних цінностей, так і носіїв іншої культури та думок, що не співпадають 3 власними.

\section{Jimepamypa}

1. Абашкіна Н.В. Нові концепції навчання і виховання у сучасній німецькій педагогіці. Київ: Інститут системних досліджень освіти, 1995. 32 с.

2. Библер В.С. Школа диалога культур. Искусство в школе. Москва, 1992. №2. С.48.

3. Відродження і розвиток культури України: проблеми історії, теорії і практики: Тези доповідей Всеукраїнської наукової конференції. Київ: Друкар. 1993. 170 с.

4. Гончаренко С. Не руйнувати, а реформувати. Товарии. 1997. №25. С.3.

5. Кант И. Критика способности суждения. Москва: Искусство, 1994. 367 с.

6. Косів М. Про духовне плебейство і не тільки. Культура і життя. 1995. № 27.

7. Луначарский А.В. Избранные статьи по эстетике/сост. А.Ермакова. Москва : Искусство, 1975. 391 с.

8. Макаренко А.С. О воспитании. Москва: Политиздат, 1988. С.27.

9. Маслов В.С. Теорія та практика культурологічного виховання. Київ: КВГІ, 1995. С.11-76.

10. Національна державна комплексна програма естетичного виховання. Проект / АПН України, Інститут українознавства КДУ ім.Т.Шевченка; Уклад. І.І. Зязюн, О.М. Семашко. Київ, 1994. С.23.

11. Педагогічні технології: Навчальний посібник для вузів / О.Падалка, А.Нісімчук, І.Смолюк та ін.; Укр. пед.ун-т ім. М.Драгоманова. Київ: Українська енциклопедія, 1995. 254 с.

12. Men Near TV. Washington Post. 1995. 18.07. P.3.

\section{References}

1. Abashkina, N.V. (1995). New conception and achievement of the presently educated teacher. Kiev: Institute of Systemic Education [in Ukrainian].

2. Bibler, V.S. (1992). School of dialogue of cultures. Iskusstvo v chkole. Moscow, 2, 48 [in Russian].

3. Revival and development of culture of Ukraine: problems of history, theory and practice (1993 These are the speakers of the All-Ukrainian Science Conference Kiev: Drukar) [in Ukrainian].

4. Goncharenko, S. (1997). Do not ruinuvati, but reformat. Tovarych, 25,3 [in Ukrainian].

5. Kant, I. (1994). Criticism of the ability of judgment. Moscow: Art [in Russian].

6. Kosiv, M. (1995). About spiritual plebeianism and not tilki. Culture and Life, 27 [in Ukrainian].

7. Lunacharsky, A.V. (1975). Selected articles on aesthetics. Moscow: Art [in Ukrainian].

8. Makarenko, A.S. (1988). About education. Moscow: Politizdat [in Ukrainian].

9. Maslov, V.S. (1995). Theory and practice of of cultural education. Kiev: KVGI, 11-76 [in Ukrainian]. Ukrainian].

10. The National State Comprehensive Program of Aesthetic Education (1994). Kiev, 23 education [in Ukrainian].

11. Pedagogical technology: The first-hand seminar for universities. (1995). Kiev: Ukrainian Encyclopedia [in

12. Men Near TV. (1995). Washington Post, 18.07, 3 [in English]..

Стаття надійшла до редакиії 10.09.2019 р. 